WIESŁAW BANACH

\title{
KULTURA A PROBLEM ZACOFANIA
}

\begin{abstract}
Banach Wiesław, Kultura a problem zacofania [Culture and the problem of backwardness] edited by W. Banach - „Człowiek i Społeczeństwo", vol. XXXVIII, Poznań 2014, pp. 121-132, Adam Mickiewicz University Press. ISBN 978-83-232-2791-5. ISSN 0239-3271.
\end{abstract}

The aim of this paper is to present and examine the link between culture and economic backwardness. One of the main questions of economic thought is: why some are so rich and some so poor? Traditional explanations like imperialism, dependency and racism are no longer adequate, and increasingly observers are concluding that the principal reason why some countries and ethnic groups are better off than others lies in cultural values, which powerfully shape political, economic and social performance. According to many authors (Lawrence E. Harrison, Samuel P. Huntington, Peter Berger, David Landes, Mariano Grondona, Francis Fukuyama, Robert Putnam, Ronald Inglehart, Michael Porter) adequate values, axiological determinants and other cultural factors (like customs, beliefs attitudes, trust in the individual, the moral imperative, the value of work) have a very positive impact on the economic development of each society. The paper is an attempt to show why the category of backwardness is more appropriate and helpful for the understanding of the role of culture than the category of development.

Wiesław Banach, Uniwersytet im. Adama Mickiewicza w Poznaniu, Wydział Nauk Społecznych, Instytut Kulturoznawstwa, Zakład Etyki Gospodarczej, ul. Szamarzewskiego 89a, 60-568 Poznań, Poland.

\section{WSTĘP}

Pomimo kryzysów gospodarczych nawiedzających dość cyklicznie społeczeństwa zachodnie współcześnie nie sposób kwestionować niezaprzeczalnych osiągnięć ekonomii jako nauki. Dostarcza ona bezsprzecznie skutecznych narzędzi, które w sposób wielce zadowalający zdolne są rozwiązywać palące problemy współczesnego świata, a nawet wskazywać możliwe zagrożenia i kierunki rozwoju. Ustalenia ekonomistów stanowią przecież podstawę gospodarczego sukcesu najbardziej rozwiniętych krajów świata. W historię rozwoju wiedzy ekonomicznej wplecione jest jednak podstawowe pytanie o przyczyny bogactwa i nędzy poszczególnych narodów, krajów czy regionów. Po upływie dokładnie dwustu lat od wydania Bogactwa narodów 
Adama Smitha, książki, która po raz pierwszy w historii myśli ekonomicznej postawiła sobie za cel wyjaśnienie tej fundamentalnej kwestii, Paul Samuelson napisał, że „nadal właściwie nie wiadomo, dlaczego ubogie kraje są biedne, a zamożne - bogate" 1 . Istnienia tego paradoksu nie można oczywiście wytłumaczyć brakiem należytego zainteresowania, staranności czy determinacji ekonomistów próbujących udzielić zadowalającej odpowiedzi na to pytanie. Poszukiwanie owej odpowiedzi, połączone z nakreślaniem różnorodnych kontekstów tak sformułowanego problemu, stało się zresztą przedmiotem wszechstronnych badań prowadzonych na innych polach szeroko pojętych nauk społecznych, zwłaszcza historii i socjologii. Pomimo że większość tych wysiłków prowadziła i nadal prowadzi do mniej lub bardziej przekonujących konstatacji, to jednak często są one nie tylko niekompatybilne, ale wręcz wykluczają się wzajemnie. Nie sposób zatem uznać, iż panuje wśród badaczy jakiś ogólny konsensus w tej materii.

Autorzy, którzy próbowali uporać się z tym - jak mawiał Thomas Robert Malthus - przedmiotem wszystkich dociekań ekonomii politycznej i odpowiedzieć na pytanie o przyczyny bogactwa i nędzy narodów, koncentrowali swoją uwagę zwłaszcza na kwestii powstania kapitalizmu. Kapitalizm bowiem - przy wszystkich swoich wadach i negatywnych konsekwencjach - jest społeczno-ekonomicznym systemem, który umożliwił zachodniemu światu trwały rozwój gospodarczy i osiągnięcie tym samym niespotykanego wcześniej poziomu cywilizacyjnego. Wyjaśniając genezę kapitalizmu, wskazywano w sposób mniej lub bardziej przekonujący - wiele różnorodnych czynników, które odegrały wiodącą $\mathrm{w}$ niej rolę. Koncentrowano się zatem wokół nauki i wynalazków, bogactw naturalnych oraz sprzyjających warunków klimatycznych i geograficznych. Argumentowano także, że okres bogactwa zachodnich krajów jest ewidentnym efektem długotrwałej eksploatacji przez nie innych krajów, regionów, kontynentów czy kultur. Chodzi tu głównie o prowadzoną przez wiele europejskich rządów politykę kolonialną i imperialną, dzięki której uzyskiwano łatwy dostęp do surowców, wykorzystywano tanią siłę roboczą oraz zdobywano lub tworzono ogromne rynki zbytu dla produkowanych przez siebie towarów, zaś sprzyjać temu miało jawne lub ukryte popieranie niewolnictwa oraz uznawanie wyzysku i eksploatacji za uzasadniony sposób prowadzenia gospodarczych i politycznych interesów ${ }^{2}$. Pomimo wskazywania na tak szeroką paletę przyczyn powstania ka-

1 P. Samuelson, Illogic of Neo-Marxian Doctrine of Unequal Exchange, [w:] Inflation, Trade and Taxes: Essays in Honor of Alice Bourneuf, eds D. Belsley et al., Ohio State University Press, Columbus 1976, s. 107. Cyt. za: D.S. Landes, Bogactwo i nędza narodów. Dlaczego jedni sa tak bogaci, a inni tak ubodzy, przeł. H. Jankowska, MUZA SA, Warszawa 2000, s. 15.

2 Na temat mocnych i słabych punktów tego typu wyjaśnień por. N. Rosenberg, L.E. Birdzell, Historia kapitalizmu, przeł. A. Doroba, Signum, Kraków 1994, s. 24-40. 
pitalizmu, większość badaczy omawianego problemu jest zgodna, że gospodarczego sukcesu Zachodu nie sposób wyjaśnić bez odwołania się do czterech grup zdarzeń określanych mianem rewolucji, które miały miejsce właśnie na gruncie cywilizacji zachodniej. „Począwszy od piętnastego wie$\mathrm{ku}$, następował tam intensywny rozwój handlu, który można uznać za rewolucję kupiecką. Trzy stulecia później, w osiemnastym wieku, miała miejsce Rewolucja Przemysłowa. Na przełomie dziewiętnastego i dwudziestego wieku drugą rewolucję przemysłową wywołało wprowadzenie energii elektrycznej i silników spalinowych. Wydaje się, że w naszych czasach rozwój systemów elektronicznego gromadzenia i przesyłania informacji, stosowanych $\mathrm{w}$ komunikacji i w systemach komputerowych, doprowadzi - o ile jeszcze nie doprowadził - do rewolucji informatycznej” ${ }^{3}$. Można oczywiście utrzymywać, że - będący skutkiem tych rewolucji - dobrobyt Zachodu jest wynikiem szczęśliwego splotu sprzyjających okoliczności. Wskazywanie na przysłowiowy łut szczęścia jest popularne zwłaszcza wśród niektórych historyków, wyjaśniających na przykład upadek systemu feudalnego jako nieprzewidywalny splot nieszczęśliwych wydarzeń, takich jak plagi, choroby, wojny czy klęski głodu, które nawiedzały czternastowieczną Europę. „Jednak jeśli - jak słusznie zwracają uwagę N. Rosenberg i L.E Birdzell piorun uderza cztery razy $\mathrm{w}$ to samo miejsce, należy się zastanowić, czy $\mathrm{w}$ topografii tego miejsca nie ma czegoś, co przyciąga pioruny" ${ }^{4}$. Wszelkie próby odpowiedzi na pytanie o europejski fenomen rozwoju gospodarczego są - trzymając się powyższej metafory - badaniem topografii tego miejsca, czyli próbą znalezienia jakichś specyficznych właściwości, które cechują jedynie zachodnie systemy społeczno-gospodarcze. Szuka się tu różnego rodzaju czynników ekonomicznych, społecznych, kulturowych, historycznych $\mathrm{i}$ innych, które nie są obecne $\mathrm{w}$ innych regionach świata, a które $\mathrm{w}$ jakikolwiek sposób przyczynić się mogły do gospodarczego i cywilizacyjnego rozwoju Zachodu.

\section{ZACOFANIE JAKO PRZEDMIOT BADAŃ}

Jak zostało wspomniane, badanie przyczyn gospodarczego rozwoju poszczególnych narodów, krajów czy regionów nie przyniosło dotąd jednoznacznie pozytywnych i satysfakcjonujących rezultatów. Podstawową trudność stanowi tu bowiem konieczność wyodrębnienia specyficznych cech konkretnego systemu społeczno-gospodarczego, których istnienie pociąga

3 Ibidem, s. 27-28.

${ }^{4}$ Ibidem, s. 28. 
za sobą możliwość wstąpienia na ścieżkę przyspieszonego rozwoju. W podejściu tym poszukuje się konstytutywnych elementów rozwoju gospodarczego, stanowiących jeśli nie warunek jego wystąpienia, to przynajmniej decydujący czynnik sprawczy. Innymi słowy, przedmiotem badań, który wymaga tutaj zdefiniowania i wyjaśnienia, pozostaje kategoria rozwoju ${ }^{5}$.

Jednak w ciągu kilku ostatnich dziesięcioleci coraz częściej i wyraźniej dostrzegamy tendencję do swoistego odwracania przez znawców przedmiotu metodologicznego porządku badań. Chodzi mianowicie o to, że za punkt wyjścia swoich ustaleń obierają oni nie kategorię rozwoju, ale kategorię zacofania. Rzecz w tym, iż niejednokrotnie kategoria zacofania w sposób znacznie bardziej trafny i rzeczowy oddaje istotę badanego problemu aniżeli kategoria rozwoju. Spostrzeżenie to przestaje nas dziwić w momencie, gdy zdamy sobie sprawę, że - spoglądając na historię ludzkości z perspektywy dzisiejszych standardów - musimy dokonać miażdżącej oceny warunków ekonomicznych, w jakich przyszło żyć naszym przodkom. Jest to bowiem historia nieustannej niedoli, niedostatku oraz braku jakichkolwiek perspektyw i szans na zmianę beznadziejnego położenia. Warto zacytować tu fragment opisu rzeczywistości, w jakiej przez większość dziejów przyszło żyć i funkcjonować człowiekowi: „W okresie przednowożytnym, w całym świecie chrześcijańskim, choroby siały spustoszenie wśród ubogich. Surowość pór roku, cykliczne nieurodzaje i wiele innych naturalnych przypadków powodowały przedłużające się okresy nędzy i nawracające głody. Bardzo często życie miało ubogiemu do zaoferowania znacznie mniej niż poziom przetrwania, a przeciętna długość życia była bardzo niska (osiemnaście lat lub mniej). Dlatego zwyczajne życie choć trochę powyżej najniższego poziomu traktowane było jak specjalne błogosławieństwo. Niewiele albo wcale nie myślano o eliminacji biedy i o zmianie warunków, w jakich żyli ubodzy. Panowała straszna nędza; rzesze żebraków wędrowały tu i tam, od czasu do czasu eksplodując w dzikich, szalonych buntach. We Francji z końcem XVIII wieku $90 \%$ ludności żyło na bardzo surowej diecie, wydając $80 \%$ swych dochodów jedynie na chleb" 6 . Jeśli zatem zgodzimy się z tezą, w myśl której historia ludzkości jest historią permanentnej ucieczki przed nędzą, zaś ubóstwo i deficyt stanowiły normę życia przeszłych pokoleń, to okaże się, że lata rozwoju, względnej prosperity czy choćby umiarkowanego dostatku

${ }^{5}$ Koncentrowanie się badaczy opisywanego nurtu na takich kategoriach, jak rozwój, postęp, dobrobyt czy bogactwo, znajduje odzwierciedlenie choćby w tytułach ich prac. Wystarczy dla przykładu przywołać „biblię” ekonomii, jaką pozostaje dzieło Adama Smitha Badania nad natura i przyczynami bogactwa narodów i w konsekwencji całą ekonomiczną dyskusję stanowiącą o istocie myśli ekonomicznej, która została zapoczątkowana tą książką.

${ }^{6}$ M. Novak, Bogactwo i cnota: rozwój chrześcijańskiej doktryny ekonomicznej, [w:] Etyka kapitalizmu, red. P. Berger, przeł. H. Woźniakowski, Signum, Kraków 1994, s. 80. 
były jedynie okresami przejściowymi, traktowanymi jako "anomalie” na gospodarczej mapie świata. Innymi słowy, normalną sytuacją, w jakiej żył i funkcjonował rodzaj ludzki, była sytuacja słabości gospodarczej i zacofania, nie zaś sytuacja rozwoju gospodarczego.

Za wzorcowy przykład takiego metodologicznego odwrócenia porządku badań może służyć klasyczna już praca jednego z antenatów paradygmatu kulturowego Edwarda Banfielda The Moral Basis of a Backward Society, w której autor skoncentrował się na kulturowych źródłach ubóstwa. Chcąc wyjaśnić przyczyny zacofania regionów południowych Włoch, opisał zjawisko, które określił jako „amoralny familizm”. Pojęcie to okazało się przydatne na gruncie nauk społecznych i znalazło zastosowanie w późniejszych tego typu analizach. Co szczególnie istotne z punktu widzenia niniejszego artykułu, opisane przez Banfielda destrukcyjne zjawisko odnosi się do zaufania7, czyli kategorii sytuowanej $\mathrm{w}$ szeroko rozumianej kulturze. $\mathrm{Z}$ tego względu po wypracowane przez autora pojęcie „amoralnego familizmu” szczególnie chętnie sięgają wszyscy ci badacze, którzy w sferze społeczno-kulturowej upatrują przyczyn ekonomicznych sukcesów bądź porażek poszczególnych krajów, regionów czy narodów. Jednym z takich badaczy, którzy - akcentując znaczenie kultury dla gospodarczej i politycznej kondycji społeczeństw $\mathrm{w}$ znacznym stopniu wykorzystali ustalenia Banfielda $\mathrm{w}$ odniesieniu do sytuacji południowych Włoch, jest Robert Putnam. Jego zdaniem wszechobecny brak zaufania do wszystkich poza własną rodziną uniemożliwia wytworzenie się czegoś, co nazywane jest kapitałem społecznym. Jego niedobór objawia się między innymi ogromnymi trudnościami w ukształtowaniu się instytucji stanowiących fundament społeczeństwa obywatelskiego. Na ten właśnie deficyt w południowych częściach Włoch wspomniany autor zwrócił szczególną uwagę w głośnej książce Demokracja w działaniu. Tradycje obywatelskie we wspótczesnych Wtoszech ${ }^{8}$.

Jeśli chodzi o przykłady prac traktujących o polskiej problematyce społeczno-gospodarczej, w których autorzy dokonali wspomnianego odwróce-

\footnotetext{
${ }^{7}$ Członkowie społeczności dotkniętych amoralnym familizmem charakteryzują się bardzo silnym zaufaniem, którym darzą tylko wybranych (członków własnej rodziny, przyjaciół, grupy interesów czy ewentualnie kolegów). Natomiast wobec pozostałych (których niejako z definicji określają jako obcych) wykazują daleko posuniętą nieufność i podejrzliwość. $\mathrm{Z}$ reguły brak jest $\mathrm{w}$ takich społecznościach nie tylko dbałości o dobro wspólne, ale nawet jego poczucia.

8 Por. R. Putnam, Demokracja w dziataniu. Tradycje obywatelskie we wspótczesnych Włoszech, przeł. J. Szacki, Znak, Fundacja im. Stefana Batorego, Kraków-Warszawa 1995. Godny odnotowania jest fakt, że książka ta okazała się najczęściej cytowaną pozycją z zakresu szeroko pojętych nauk społecznych $\mathrm{w}$ okresie ostatniej dekady XX wieku. Świadczy on niewątpliwie o rzeczywistym zainteresowaniu kulturą jako czynnikiem, przez pryzmat którego należy spoglądać na współczesne zjawiska świata społecznego, politycznego i gospodarczego.
} 
nia porządku badań, to bez wątpienia godna odnotowania jest książka Anny Sosnowskiej Zrozumieć zacofanie. Spory historyków o Europe Wschodnia (19471994). Autorka prezentuje w niej modele historyków polskich (Witolda Kuli, Andrzeja Wyczańskiego, Jerzego Topolskiego, Mariana Małowista) oraz innych badaczy (m.in. Immanuela Wallersteina, Ivána Berenda, Geőrgy Ránki, Fernanda Braudela, Roberta Brennera, Perry'ego Andersona, Jenő Szúcsa), które miały na celu uchwycenie i wyjaśnienie fenomenu Europy Wschodniej. Wychodzi ona z założenia, „że zmienną, którą można wyjaśnić genetycznie przez odwołanie się do przeszłości społecznej, jest wschodnioeuropejskie zacofanie gospodarcze. Założenie to jest chyba niekontrowersyjne. [...] Zakładam też - pisze autorka - i jest to założenie bardziej kontrowersyjne niż poprzednie - że to właśnie zacofanie stanowiło w nowożytnej historii o ciągłości społeczeństw regionu. Zacofanie to traktuję jako strukturę długiego trwania $[\ldots]^{\prime \prime}$. Stwierdzić zatem można, że Europa Wschodnia traktowana jest tutaj jako region, w historię którego wpisany był problem zacofania względem Europy Zachodniej. Wskazanie na genezę długotrwałych procesów i tendencji, których negatywne skutki objawiają się często po wielu dekadach lub nawet wiekach, może stanowić podstawę udzielenia satysfakcjonujących wyjaśnień na temat braku - istotnych z punktu widzenia rozwoju gospodarczego - wartości, norm, praktyk, instytucji społecznych itd.

Koncentrując swoją uwagę badawczą na kategorii zacofania, musimy jednak zdawać sobie sprawę z co najmniej dwóch trudności. Po pierwsze, termin "zacofanie" z etymologicznego punktu widzenia jest synonimem zapóźnienia i oznacza, że używający go autor - explicite bądź implicite - zakłada istnienie jakiegoś punktu odniesienia, który w procesie gospodarczego bądź cywilizacyjnego rozwoju stoi wyżej od badanego przez niego obiektu. Po drugie, jeśli ktoś utrzymuje, iż jakiś region, naród czy społeczność niemal od zawsze boryka się z problemem zacofania, narazić się może na zarzut determinizmu. Determinizm zakłada bowiem, że jakaś immanentna cecha

${ }^{9}$ A. Sosnowska, Zrozumieć zacofanie. Spory historyków o Europę Wschodnia (1947-1994), Wydawnictwo TRIO, Warszawa 2004, s. 19. Na marginesie warto zauważyć, że formułując swoją tezę i traktując zacofanie jako strukturę długiego trwania, autorka nawiązuje do ustaleń francuskiej szkoły historycznej, a zwłaszcza Fernanda Braudela, który - w odniesieniu do interesującego nas tu problemu zacofania - zwykł był mawiać, że „Biedny kraj jest biedny, ponieważ jest biedny" (zob. F. Braudel, Kultura materialna, gospodarka i kapitalizm XV-XVIII wiek, t. 3: Czas świata, przeł. J. i J. Strzeleccy, PIW, Warszawa 1992, s. 35). Gwoli ścisłości zaznaczyć należy, że autorem przywołanych słów nie jest Braudel, ale estoński ekonomista Ragnar Nurkse (zob. R. Nurkse, Problemy tworzenia kapitału w krajach gospodarczo słabo rozwiniętych, przeł. L. Niżyński, PWN, Warszawa 1962, s. 26), który stworzył teorię tzw. zaklętego kręgu ubóstwa. Braudel podchwycił i rozpowszechnił - zwłaszcza na gruncie historii - wyrażoną w cytacie myśl. 
systemu przesądza (albo - jak sama nazwa stanowiska wskazuje - determinuje) o wystąpieniu pewnej sekwencji zdarzeń nieuchronnie prowadzących do określonego stanu rzeczy. W przypadku Europy Wschodniej cechą taką mógłby być na przykład brak należytego zespołu instytucji, praw i mechanizmów, które stanowią warunek sprawnego funkcjonowania systemu rynkowego ${ }^{10}$.

\section{KULTURA A PROBLEM ZACOFANIA}

Oprócz autorów badających historię i specyfikę wschodnioeuropejskiego zacofania coraz bardziej znaczące stają się wystąpienia badaczy południowoamerykańskich, którzy próbują nie tylko wyjaśnić problem zacofania wpisany w obraz południowej części świata, ale także przeciwdziałać mu. W dyskusji o przyczynach zacofania autorzy ci mają swego rodzaju „przewagę" nad swoimi kolegami z północnej czy zachodniej półkuli, gdyż z powodu urodzenia i często zamieszkania - dysponują znacznie szerszym oglądem sytuacji i dokładniejszym wglądem w poszczególne problemy społeczno-gospodarcze, z jakimi borykają się ich rodzime kraje. Za przykład naukowego zmierzenia się $\mathrm{z}$ tym zagadnieniem może posłużyć typologia kultur, którą zaproponował argentyński intelektualista Mariano Grondona ${ }^{11}$. Co ważne, zwłaszcza w kontekście podjętej w niniejszym artykule oraz całym tomie problematyki, typologia ta stanowi jedno $\mathrm{z}$ najbardziej reprezentatywnych wystąpień współczesnych badaczy, którzy głównych przyczyn gospodarczego sukcesu bądź niepowodzenia poszczególnych społeczności upatrują wśród czynników kulturowych, a zwłaszcza aksjologicznych. Do grona tych autorów należą m.in.: Francis Fukuyama, Samuel Huntington, Lawrence E. Harrison, Peter Berger, Robert Putnam, Ronald Inglehart, Michael Porter czy David Landes ${ }^{12}$. Niezależnie od uprawianej dziedziny wie-

\footnotetext{
${ }^{10}$ Jednym z bardziej znanych przykładów deterministycznego stanowiska jest sławna hipoteza homo sovieticus. Omawiam ją szerzej w artykule Refleksja nad koncepcja folwarcznych korzeni polskiej kultury gospodarczej Janusza Hryniewicza (w niniejszym tomie, s. 49-65).

11 Por. M. Grondona, Kulturowa typologia rozwoju gospodarczego, [w:] Kultura ma znaczenie. Jak wartości wptywaja na rozwój społeczeństw, red. L.E. Harrison, S.P. Huntington, przeł. S. Dymczyk, Zysk i S-ka Wydawnictwo, Poznań 2003, s. 101-115. Tytuł pracy Grondony, podobnie jak całego tomu zredagowanego przez Harrisona i Huntingtona, może sugerować, że głównym przedmiotem dociekań pozostaje kategoria rozwoju. Tak jest w istocie, choć należy podkreślić, że konstrukcja omawianej typologii (usytuowanie na przeciwległych biegunach dwóch odmiennych typów systemu wartości: prorozwojowego i antyrozwojowego) przesądza o równoczesnym zainteresowaniu autora warunkami rozwoju, $\mathrm{z}$ jednej strony, oraz determinantami zacofania - $\mathrm{z}$ drugiej.

12 Literatura dotycząca opisywanego tu podejścia jest bardzo bogata. Jako przykład publikacji odzwierciedlającej poglądy, licznie reprezentowanego w niniejszym tomie, poznańskiego
} 
dzy (filozofia, socjologia, politologia, historia, ekonomia) punktem wyjścia i wspólnym mianownikiem ich ustaleń jest argumentacja na rzecz tezy, że „kultura ma znaczenie” (culture matters). To oni właśnie są spadkobiercami podejścia zapoczątkowanego przez Maxa Webera, którego analizy protestanckich korzeni kapitalizmu weszły do kanonu nowożytnej myśli społecznej ${ }^{13}$. W anglojęzycznej literaturze przedmiotu reprezentowany przez nich nurt określa się jako cultural turn, czyli tendencję do opisywania i wyjaśniania różnorodnych zjawisk świata gospodarczego i politycznego przez pryzmat kultury stanowiącej rezerwuar tradycyjnie ukształtowanych wartości, norm, obyczajów czy zasad. Nie wchodząc w szczegóły typologii Grondony, należy podkreślić, że autor ten nie poprzestaje na przedstawieniu ogólnych warunków, które jego zdaniem muszą być spełnione, aby można było mówić o zrównoważonym rozwoju (względnie długotrwałym zacofaniu) społeczno-gospodarczym. Wykorzystując ustalenia L.E. Harrisona zawarte w książce Underdevelopment is a State of Mind ${ }^{14}$, stara się wskazać na wiele konkretnych czynników, które - mieszcząc się w sferze szeroko pojętej kultury - mają decydujące znaczenie dla rozwoju bądź zacofania poszczególnych krajów. Zestawiając prorozwojowy typ systemu wartości z typem antyrozwojowym, Grondona wymienia takie kulturowe czynniki, jak: religia, wiara $\mathrm{w}$ jednostkę, imperatyw moralny (zgodność istniejących norm społecznych $\mathrm{z}$ rzeczywistym ich przestrzeganiem), odmienne $\mathrm{w}$ obu typach systemów poglądy na temat bogactwa, konkurencji oraz sprawiedliwości, wartość pracy, rola herezji, cele i funkcje edukacji, znaczenie użyteczności, występowanie i akceptacja dla tzw. "cnót mniejszych” (np. solidności, uprzejmości, porządku, punktualności itp.), stosunek do czasu, różne sposoby pojmowania racjonalności, charakter władzy, dominujący światopogląd, czy też ogólny pogląd na życie (optymizm versus pesymizm). Owe kulturowe czynniki determinują podejmowanie lub - co tutaj szczególnie ważne - powstrzymywanie się od określonych działań gospodarczych czy społecznych. To one właśnie - zdaniem tego autora - mają w postawionej na początku artykułu kwestii decydujące znaczenie, przesądzając o sukcesie bądź niepowodzeniu poszczególnych krajów. Typologia ta może stanowić swego rodzaju narzędzie czy wzorzec umożliwiający mniej lub bardziej pre-

ośrodka kulturoznawczego podać można zeszyt „Kultury Współczesnej” (2008, nr 1(55), red. J. Sójka) zatytułowany Kulturoznawca w świecie gospodarki, poświęcony w całości oddziaływaniu kultury na gospodarkę.

${ }^{13}$ Por. M. Weber, Etyka protestancka a duch kapitalizmu, przeł. J. Miziński, Wydawnictwo TEST, Lublin 1994, oraz tekst A. Dylus, Wyznaniowe zróżnicowanie kultury gospodarczej. O ideologicznym nadużyciu znanej tezy (w niniejszym tomie, s. 67-80).

${ }^{14}$ L.E. Harrison, Underdevelopment is a State of Mind, Harvard Center for International Affairs, University Press of America, Cambridge 1985. 
cyzyjne określenie typu (prorozwojowy versus antyrozwojowy) systemu wartości konkretnych krajów czy społeczeństw. Innymi słowy, długotrwały rozwój albo zacofanie społeczno-gospodarcze są, według Grondony, procesami uwarunkowanymi kulturowo. Co więcej, jeśli zgodzimy się z opinią, że owe aksjologiczne czynniki sytuują się w tej sferze kultury, którą zwykliśmy nazywać etyką; jeżeli przyznamy, że jednostka działa moralnie, kiedy przestrzega powszechnie akceptowanych wartości i norm; jeśli wreszcie założymy, że długotrwały sukces czy niepowodzenie uzależnione są od wartości pozaekonomicznych będących jednocześnie wartościami proekonomicznymi, to musimy stwierdzić, iż takie kategorie ekonomiczne jak rozwój czy zacofanie gospodarcze są zjawiskami moralnymi ${ }^{15}$.

Innym autorem badającym przyczyny południowoamerykańskiego zacofania jest znany peruwiański reformator Hernando de Soto. W głośnej książce Tajemnica kapitatu. Dlaczego kapitalizm triumfuje na Zachodzie, a zawodzi gdzie indziej podejmuje się odpowiedzi na postawione $\mathrm{w}$ tytule pytanie, lecz dochodzi do diametralnie innych konstatacji niż Grondona. Po pierwsze, de Soto nie uważa, aby kraje Trzeciego Świata (a także kraje postkomunistyczne) były aż tak biedne, jak się powszechnie sądzi. Społeczeństwa tych krajów nie są dotknięte żadnym paraliżem stanowiącym jakąkolwiek przeszkodę $\mathrm{w}$ podejmowaniu przedsiębiorczych działań, zaś ich kulturom nie brak niczego, co uniemożliwiałoby wstąpienie na ścieżkę przyspieszonego rozwoju. Podstawową przyczyną kiepskiej kondycji systemów gospodarczych owych krajów jest - zdaniem tego autora - to, że ogromna część ich kapitału to tzw. martwy kapitał. Składają się na niego zwłaszcza domy mieszkalne oraz inne nieruchomości, które ze względu na brak prawa własności nie mogą stanowić wystarczających gwarancji kredytowych. Jak przekonuje de Soto, „co najmniej $80 \%$ ludności tych krajów nie może tchnąć życia w swój majątek i wykorzystać go do wytworzenia kapitału, ponieważ prawo wzbrania im dostępu do formalnego systemu własności. Mają oni kapitał wart biliony dolarów, lecz jest to kapitał martwy. [...] Nie ma sensu zachęcać ich do cierpliwego wyczekiwania, aż korzyści kapitalizmu same wpadną im do rąk. To się nigdy nie stanie, dopóki nie położy się trwałych fundamentów formalnej własności"16.

Stanowisko autora w kwestii przyczyn zacofania wspomnianych krajów wydaje się być nieprzejednane. Odrzuca on wszelkie próby wyjaśnień odwołujących się do szeroko pojętej kultury i argumentuje na rzecz tezy o konieczności podjęcia przez państwo określonych działań ustawodawczych

15 Por. M. Grondona, op. cit., s. 103.

${ }^{16} \mathrm{H}$. de Soto, Tajemnica kapitatu. Dlaczego kapitalizm triumfuje na Zachodzie, a zawodzi gdzie indziej, przeł. S. Czarnik, Fijorr Publishing, Warszawa-Chicago 2002, s. 236. 
i administracyjnych. Działania te, jako konieczny warunek wstąpienia na ścieżkę rozwoju, są czynnikiem wystarczającym do stworzenia wolnorynkowych mechanizmów oraz wyzwolenia gospodarczej inicjatywy. „Pokornie sugeruję zatem - wyznaje autor - abyśmy - zanim jakiś mędrzec żyjący wewnątrz szklanego klosza spróbuje nas przekonać, że sukces w kapitalizmie wymaga określonych walorów kulturowych - przekonali się najpierw, co będzie, gdy kraje rozwijające się i postkomunistyczne wprowadzą u siebie scalone systemy własności, mogące wytworzyć kapitał dla każdego"17.

Należy na zakończenie zadać nieco ogólniejsze, lecz zasadnicze pytanie o korzyści wynikające $\mathrm{z}$ tego, że przedmiotem badań uczynimy kategorię zacofania. Co przyniesie nam próba ustalenia nie przyczyn rozwoju, ale właśnie przyczyn zacofania? Otóż, dokonując nakreślonego powyżej odwrócenia problemu badawczego, jesteśmy w stanie pokusić się o ustalenie zespołu wartości, norm, obyczajów, postaw, praktyk, instytucji czy struktur społecznych, których brak jest podstawowym powodem gospodarczego i cywilizacyjnego zapóźnienia. Odwołując się do metody porównawczej czy też tworząc typologie, badacz jest w stanie przekonująco wykazać, iż deficyt takiego bądź innego elementu społeczno-kulturowej rzeczywistości mógł mieć pierwszorzędne znaczenie dla niewykształcenia się gospodarczych instytucji będących podstawą rozwoju. Mówiąc w pewnym uproszczeniu, $\mathrm{w}$ podejściu tym szukamy nie cech przesądzających o rozwoju, ale cech przesądzających o zacofaniu danego regionu, narodu czy społeczności. Niniejszy artykuł jest $\mathrm{w}$ założeniu próbą refleksji nad zasadnością swego rodzaju metodologicznego odwrócenia porządku badań, a jednocześnie potraktowania gospodarki nie jako samoistnego bytu, lecz jako rzeczywistości stanowiącej element szerszego systemu powiązań.

Natomiast chcąc się odnieść do tytułowej kwestii związków łączących kulturę z życiem gospodarczym, a zwłaszcza z problemem zacofania, musimy stwierdzić, że niezmiernie trudno jest dojść do jednoznacznych konkluzji i udzielić prostych odpowiedzi. Należy uświadomić sobie, iż ukazanie w sposób niepodważalny konkretnych, namacalnych korzyści wynikających $\mathrm{z}$ panowania $\mathrm{w}$ jakiejś przestrzeni społeczno-ekonomicznej określonego sys-

17 Ibidem, s. 250. Warto zauważyć, że niechęć de Soto do wyjaśnień rozwoju gospodarczego akcentujących rolę kultury bierze się także z braku zaufania do intelektualistów. Autor przywołuje fragment jednego z artykułów „Foreign Affairs”, w którym czytamy: „Kultura jest w modzie. [...] Wyjaśnienia kulturowe utrzymują się, ponieważ intelektualiści je lubią. Czynią one wartościową szczegółową wiedzę na temat historii różnych krajów, której oni, intelektualiści, mają pod dostatkiem. Przydają aury tajemniczości i skomplikowania studiom nad społeczeństwami. [...] Lecz kulturę jako taką można kształtować i zmieniać. Za tak licznymi postawami kulturowymi, gustami i preferencjami stoją kształtujące je siły polityczne i gospodarcze", ibidem, s. 251. 
temu wartości nie jest właściwie możliwe. Możliwe jest jednak - jak czynią to liczni autorzy - przekonujące argumentowanie na rzecz tezy, że to, co zwykło się nazywać sferą aksjologiczną, ma kapitalne znaczenie dla sprawnego funkcjonowania mechanizmów gospodarczych. Dotrzymywanie umów, solidność, prawdomówność, zaufanie, odpowiedzialność, punktualność to tylko niektóre spośród wielu wartości umożliwiających wykształcenie swoistego etosu gospodarczego.

Nie można oczywiście nie dostrzegać argumentów tych badaczy, którzy bardzo sceptycznie odnoszą się do roli kultury jako czynnika przesądzającego o gospodarczym sukcesie. Hernando de Soto i jemu podobni słusznie zauważają, że niejednokrotnie gospodarcze i cywilizacyjne zacofanie daje się nie tylko wyjaśnić, ale także skutecznie zwalczyć za pomocą stosunkowo prostych zabiegów prawno-administracyjnych. Biorąc pod uwagę zasadę Ockhama - aby nie mnożyć bytów ponad potrzebę i zawsze, kiedy to tylko możliwe, odwoływać się do najprostszych wyjaśnień - trudno odmówić im racji. Niestety, sprawa jest jednak nieco bardziej skomplikowana i nie zawsze postawienie właściwej diagnozy oraz zastosowanie odpowiednich środków jest tak proste i bezdyskusyjne. Przedmiot tzw. kultury gospodarczej (czy jak nazywa ją Peter L. Berger - kulturoznawstwa gospodarczego) dostarcza nam wielu tego typu przykładów. Jednym z nich może być gospodarcze i cywilizacyjne zróżnicowanie północnych oraz południowych Włoch. Jak bowiem wytłumaczyć, na gruncie argumentacji de Sota, dlaczego kraj będący od prawie półtora wieku jednolitym państwem, funkcjonującym na podstawie tych samych struktur prawnych i administracyjnych, jest tak znacznie spolaryzowany. Co sprawia, że jego śródziemnomorskie obszary jawią się na tle północnych jako regiony niezmiernie zacofane?

\section{BIBLIOGRAFIA}

Banach W., Refleksja nad koncepcja folwarcznych korzeni polskiej kultury gospodarczej Janusza Hryniewicza, "Człowiek i Społeczeństwo" 2014, t. 38.

Braudel F., Kultura materialna, gospodarka i kapitalizm XV-XVIII wiek, t. 3: Czas świata, przeł. J. i J. Strzeleccy, PIW, Warszawa 1992.

Dylus A., Wyznaniowe zróżnicowanie kultury gospodarczej. O ideologicznym nadużyciu znanej tezy, "Człowiek i Społeczeństwo" 2014, t. 38.

Grondona M., Kulturowa typologia rozwoju gospodarczego, [w:] Kultura ma znaczenie. Jak wartości wptywaja na rozwój społeczeństw, red. L.E. Harrison, S.P. Huntington, przeł. S. Dymczyk, Zysk i S-ka Wydawnictwo, Poznań 2003.

Harrison L.E., Underdevelopment is a State of Mind, Harvard Center for International Affairs and Lanham, University Press of America, Cambridge 1985. 
Landes D.S., Bogactwo i nędza narodów. Dlaczego jedni są tak bogaci, a inni tak ubodzy, przeł. H. Jankowska, MUZA SA, Warszawa 2000.

Novak M., Bogactwo i cnota: rozwój chrześcijańskiej doktryny ekonomicznej, [w:] Etyka kapitali$z m u$, red. P. Berger, przeł. H. Woźniakowski, Signum, Kraków 1994.

Nurkse R., Problemy tworzenia kapitatu w krajach gospodarczo stabo rozwiniętych, przeł. L. Niżyński, PWN, Warszawa 1962.

Putnam R., Demokracja w działaniu. Tradycje obywatelskie we wspótczesnych Włoszech, przeł. J. Szacki, Znak, Fundacja im. Stefana Batorego, Kraków-Warszawa 1995.

Rosenberg N., Birdzell L.E., Historia kapitalizmu, przeł. A. Doroba, Signum, Kraków 1994.

Samuelson P., Illogic of Neo-Marxian Doctrine of Unequal Exchange, [w:] Inflation, Trade and Taxes: Essays in Honor of Alice Bourneuf, eds D. Belsley et al., Ohio State University Press, Columbus 1976.

Sosnowska A., Zrozumieć zacofanie. Spory historyków o Europę Wschodnia (1947-1994), Wydawnictwo TRIO, Warszawa 2004.

de Soto H., Tajemnica kapitatu. Dlaczego kapitalizm triumfuje na Zachodzie, a zawodzi gdzie indziej, przeł. S. Czarnik, Fijorr Publishing, Warszawa 2003.

Weber M., Etyka protestancka a duch kapitalizmu, przeł. J. Miziński, Wydawnictwo TEST, Lublin 1994. 